DOI: https://doi.org/10.24127/ajpm.v10i1.3154

\title{
MODUL PEMBELAJARAN MATEMATIKA BERBASIS STRATEGI HIGHER ORDER THINKING (HOT) TERHADAP KEMAMPUAN BERPIKIR TINGKAT TINGGI
}

\author{
Utin Desy Susiaty $^{1 *}$, Dwi Oktaviana ${ }^{2}$ \\ $1^{*}, 2$ IKIP PGRI Pontianak, Pontianak, Indonesia \\ *Corresponding author. Jalan Danau Sentarum, 78116, Pontianak, Indonesia. \\ Email: d3or4f4ty4@gmail.com ${ }^{1 *)}$ \\ dwi.oktaviana7@gmail.com $^{2)}$
}

Received 12 October 2020; Received in revised form 31 January 2021; Accepted 02 April 2021

\begin{abstract}
Abstrak
Penelitian ini bertujuan untuk mengetahui tingkat kevalidan, kepraktisan dan keefektifan modul pembelajaran matematika berbasis strategi HOT terhadap kemampuan berpikir tingkat tinggi siswa SMP. Metode penelitian yang digunakan dalam penelitian ini adalah metode penelitian dan pengembangan (R\&D) dengan rancangan 4-D menurut Thiagarajan yang merupakan perpanjangan dari Define (Pendefinisian), Design (Perancangan), Development (Pengembangan), and Dessemination (Penyebaran). Subjek dalam penelitian ini adalah 35 siswa SMP Koperasi Pontianak. Instrumen dalam peneltiian ini adalah lembar validasi ahli, angket dan tes. Berdasarkan hasil pengembangan, penelitian, dan pembahasan terhadap modul pembelajaran matematika berbasis strategi HOT terhadap kemampuan berpikir tingkat tinggi siswa SMP dapat simpulkan bahwa: (1) modul pembelajaran matematika berbasis strategi HOT terhadap kemampuan berpikir tingkat tinggi siswa SMP memenuhi kriteria valid dengan kategori sangat valid, kriteria praktis dengan kategori sangat praktis dan memenuhi kriteria efektif.
\end{abstract}

Kata kunci: Berpikir tingkat tinggi; matematika; strategi HOT.

\begin{abstract}
This study aims to determine the level of validity, practicality and effectiveness of the HOT strategy-based mathematics learning module on the high order thinking skills of junior high school students. The research method used in this research is the method of research and development $(R \& D)$ with a 4-D design according to Thiagarajan which is an extension of Define, Design, Development, and Dessemination. The subjects in this study were 35 students of the Pontianak Cooperative Junior High School. The instruments in this research were expert validation sheets, questionnaires and tests. Based on the results of the development, research, and discussion of the HOT strategy-based mathematics learning module on junior high school students 'high-order thinking skills, it can be concluded that: (1) the HOT strategy-based mathematics learning module for junior high school students' high-order thinking skills meets the valid criteria with very valid category, practical criteria with very practical category and fulfilling the effective criteria.
\end{abstract}

Keywords: Higher order thinking; HOT strategy; mathematics.

This is an open access article under the Creative Commons Attribution 4.0 International License

\section{PENDAHULUAN}

Tingkat kemampuan berpikir dalam matematika dibedakan menjadi dua tatanan yaitu Low Order Thinking atau tatanan rendah (mengingat, memahami, dan mengaplikasikan) dan Higher Order Thinking atau tatanan tingkat tinggi (menganalisis, mengevaluasi, dan mencipta). Akan tetapi, pada kenyataannya tergambar proses pembelajaran matematika selama ini adalah pemberian soal-soal kepada siswa dengan tingkat kemampuan berpikir pada tatanan rendah. Oleh karena itu, ketika siswa dihadapkan dengan soal-soal yang memuat kemampuan berpikir tingkat tinggi 
maka siswa akan mengalami kesulitan dalam menyelesaikan soal tersebut.

Berdasarkan studi pendahuluan yang dilakukan pada salah satu sekolah yaitu SMP Koperasi Pontianak dimana lewat penelitian sebelumnya diberikan instrumen soal kemampuan berpikir tingkat tinggi yang telah dikembangkan kepada siswa dimana hasil yang didapatkan terkait hasil analisis indeks kesukaran soal butir soal dimana semua soal masih tergolong soal sukar (Susiaty \& Oktaviana, 2019). (Oktaviana \& Susiaty, 2020) menyatakan bahwa analisis potensial efek terhadap penggunaan instrumen tes materi perbandingan berdasarkan Revisi Taksonomi Bloom untuk mengukur HOTS siswa mencapai tingkat keefektifan sebesar $68.96 \%$ dengan kriteria efek potensial yang positif. Hal ini menunjukkan bahwa siswa belum terbiasa dihadapkan dengan soal dengan tingkat kemampuan berpikir tingkat tinggi. Padahal sekolah tersebut telah menggunakan kurikulum 2013 namun berdasarkan wawancara yang dilakukan dengan salah satu guru juga menyatakan bahwa pada saat pembelajaran siswa juga tidak difokuskan pada pemberian soal dengan kemampuan berpikir tingkat tinggi namun lebih banyak diberikan soal kepada kemampuan berpikir tingkat rendah. Pada saat pembelajaran, guru juga masih menggunakan metode ceramah dan tanya jawab. Pembelajaran dengan menggunakan metode tersebut belum mendorong siswa belajar secara mandiri. Bahan ajar yang digunakan di sekolah masih berupa buku paket dan LKS dimana LKS yang digunakan merupakan terbitan dari penerbit.

Pada penelitian Rizta et al (2013) menunjukkan hasil penelitian bahwa sebesar $57 \%$ persentasi waktu pembelajaran matematika di Indonesia lebih banyak digunakan untuk membahas atau mendiskusikan soalsoal dengan kompleksitas rendah, dan hanya sekitar 3\% waktu digunakan untuk membahas soal-soal dengan kompleksitas tinggi. Tidaklah heran jika kemampuan siswa Indonesia masih lemah terhadap soal-soal dengan kemampuan berpikir tingkat tinggi. Menurut Istiyono et al (2014) peserta didik dituntut tidak hanya memiliki kemampuan berpikir tingkat rendah (lower order thinking), tetapi sampai pada kemampuan berpikir tingkat tinggi (higher order thinking, HOT). Untuk mengetahui kemampuan berpikir tingkat tinggi seseorang, maka diperlukan indikator-indikator yang mampu mengukur kemampuan tersebut (Kurniati et al., 2016). Maka dari itu perlu diadakan pembelajaran yang dapat melatih kemampuan berpikir peserta didik (Saregar et al., 2016). Menurut Fitriani et al (2018) bagi seorang siswa, kemampuan berpikir tingkat tinggi dapat dibiasakan melalui aktivitas pembelajaran. Woolfolk (Mustapa, 2014) menyatakan pembelajar yang memiliki keterampilan berfikir tingkat tinggi (Higher Order Thinking Skills) mampu membedakan antara fakta dan opini, mengidentifikasi informasi yang relevan, memecahkan masalah, dan mampu menyimpulkan informasi yang telah dianalisisnya. Hal tersebutlah yang mendasari perlunya sebuah bahan ajar yang sesuai dengan tuntutan dan harapan dalam kurikulum 2013. Keberhasilan dalam pembelajaran, selain tergantung metode yang digunakan juga sangat tergantung pada perangkat pembelajaran yang digunakan (Tjiptiany et al., 2016). Oleh karena itu, peneliti akan melanjutkan penelitian yang pernah dilakukan dengan mengembangkan modul pembelajaran matematika yang menitikberatkan 
kepada kemampuan berpikir tingkat tinggi.

Fatikhah \& Izzati (Mardiah et al., 2018) menyatakan bahwa mengembangkan modul siswa dapat belajar dengan mandiri sesuai metode yang digunakan dalam pembuatan modul. Pembelajaran modul akan lebih efektif, efisien dan relevan dibandingkan dengan pembelajaran dengan menggunakan metode ceramah yang cendrung bersifat klasikal dan dilaksanakan dengan tatap muka (Anggoro, 2015).

Beberapa penelitian yang mengembangkan modul pembelajaran matematika diantaranya: (1) Tjiptiany et al (2016) yang mengembangkan modul pembelajaran matematika dengan pendekatan inkuiri dengan hasil pengembangan modul pembelajaran matematika peluang berdasarkan pendekatan inkuiri dikatakan valid, praktis, dan efektif; (2) Lestari \& Handayani (2018) mengembangkan modul matematika berbasis matematika realistik dengan temuan penelitian yaitu dihasilkan suatu bahan ajar berbentuk modul yang sesuai dengan tujuan pembelajaran matematika peserta didik kelas VII SMP pada semester, dan (3) Mardiah et al (2018) mengembangkan modul pembelajaran matematika berbasis etnomatika menggunakan metode inkuiri dengan hasil penelitian modul pembelajaran matematika berbasis etnomatika menggunakan metode inkuiri siap digunakan sebagai bahan ajar. Oleh karena itu, dapat dikatakan modul pembelajaran sangat efektif digunakan sebagai sumber dalam pembelajaran.

Pada penelitian ini, agar proses pembelajaran siswa terlibat aktif dan menfasilitasi kemampuan berpikir tingkat tinggi siswa maka modul harus dikemas dalam pembelajaran berbasis konstruktivis yang memberikan peluang kepada siswa untuk mengonstruksi pengetahuannya sendiri dan menumbuhkembangkan sikap mandiri yaitu strategi HOT. Strategi pembelajaran HOT dipandang sebagai salah satu metode yang baik untuk mengasah kemampuan berpikir siswa.

Pembelajaran HOT termasuk salah satu strategi pembelajaran berupa rencana tindakan termasuk penggunaaan metode dan pemanfaatan berbagai sumber daya/kekuatan dalam pembelajaran. Strategi pembelajaran ini memiliki susunan langkah-langkah pembelajaran yang diarahkan untuk meningkatkan proses dan hasil belajar siswa. Retnoasih (2018) menyatakan bahwa pembelajaran HOTS diperlukan perencanaan terkait karakteristik materi, peserta didik dan dibutuhkan media pendukung pembelajaran. Gunawan (Zalukhu \& Ziraluo, 2018) mengemukakan HOT adalah proses berpikir yang mengharuskan siswa untuk memanipulasi informasi dan ideide dalam cara tertentu yang memberi mereka pengertian dan implikasi baru. Oleh karena itu, dapat disimpulkan bahwa strategi pembelajaran $H O T$ dapat menunjang kemampuan berpikir tingkat tinggi siswa.

Berdasarkan paparan kebutuhan siswa serta karakteristik strategi pembelajaran HOT tersebut disadari bahwa diperlukan suatu sumber belajar yang dapat memfasilitasi kemampuan berpikir tingkat tinggi pada level menganalisis, mengevaluasi, dan mencipta. Dilakukannya pengembangan modul pembelajaran matematika berbasis strategi HOT diharapkan menjadi salah satu pedoman guru dalam mengembangkan bahan ajar khususnya terhadap kemampuan berpikir tingkat tinggi. Oleh karena itu, perlu dikembangkan modul pembelajaran 
matematika berbasis strategi HOT terhadap kemampuan berpikir tingkat tinggi siswa SMP.

\section{METODE PENELITIAN}

Penelitian ini merupakan penelitian pengembangan. Rancangan penelitian yang digunakan adalah model pengembangan 4-D menurut Thiagarajan (Sugiyono., 2016) yang mengemukakan bahwa langkah-langkah penelitian dan pengembangan di singkat dengan 4-D merupakan perpanjangan dari Define (Pendefinisian) yang bertujuan untuk memperoleh informasi tentang permasalahan yang ada di lapangan untuk membantu mengembangkan bahan ajar yang ada sebelumnya, Design (Perancangan) yang dilakukan untuk merancang suatu produk pengembangan yang disesuaikan dengan permasalahan yang diperoleh dilapangan pada saat tahap pendefinisian,

Development

(Pengembangan) yang bertujuan untuk memperbaiki modul pembelajaran matematika berbasis strategi HOT yang akan dikembangkan dengan melakukan evaluasi dan revisi sebelum menjadi produk yang valid, and Dessemination (Penyebaran) yang berisi kegiatan menyebarluaskan produk yang telah teruji untuk dimanfaatkan orang lain. Subjek uji coba produk pada penelitian ini adalah 35 siswa SMP Koperasi Pontianak. Pemilihan subjek pada uji coba terbatas menggunakan teknik Purposive Sampling. Pemilihan uji coba terbatas dilakukan atas pertimbangan guru mata pelajaran. Lokasi dalam penelitian ini adalah SMP Koperasi Pontianak.

Teknik pengumpulan data yang digunakan dalam penelitian ini adalah: (1) teknik pengukuran dengan tes dan data hasil pengerjaan soal tes dalam modul pembelajaran matematika berbasis strategi HOT; (2) teknik komunikasi tidak langsung untuk melihat kevalidan dan kepraktisan modul pembelajaran matematika berbasis strategi HOT yang dikembangkan berupa angket (kuesioner) dan lembar validasi ahli. Teknik analisis data yang digunakan dalam penelitian ini adalah: (1) untuk menjawab kevalidan pada penelitian ini, data diperoleh berdasarkan penilaian oleh validator terhadap modul pembelajaran matematika berbasis strategi HOT. Penilaian ini dilakukan dengan angket validasi materi dan media; (2) untuk menjawab kepraktisan digunakan data kuantitatif yang didapat dari hasil angket respon siswa dan guru dengan menggunakan skala likert; (3) untuk menjawab keefektifan pada penelitian ini, digunakan statistik deskriptif untuk menganalisis data menggunakan desain pretest-posttest kelompok tunggal (The One Group Pretest-Posttest). Dalam penelitian ini hanya menggunakan satu kelompok sampel yaitu kelompok eksperimen yang mana sebelum diberikan perlakuan, mahasiswa terlebih dulu diberikan pretest kemudian posttest setelah mendapatkan perlakuan, sehingga hasil penelitian dapat lebih akurat karena membandingkan keadaan sebelum dan sesudah diberikan perlakuan. Pada uji coba lapangan data dihimpun dengan menggunakan posttest untuk mengetahui perbedaan kemampuan pemecahan masalah matematis siswa kelompok eksperimen sesudah menggunakan produk pengembangan berupa modul pembelajaran matematika berbasis strategi HOT terhadap kemampuan berpikir tingkat tinggi siswa SMP. Teknik analisis data menggunakan uji $\mathrm{t}$ paired samples dengan SPSS 16.0. 


\section{HASIL DAN PEMBAHASAN}

Pada penelitian ini dimulai dengan tahap pendefinisian dimana pada tahap ini langkah pertama yang dilakukan adalah menentukan masalah. Setelah mengidentifikasi masalah yang dialami siswa, maka selanjutnya menentukan solusi yang akan ditawarkan. Saat melakukan tahap ini dilakukan wawancara terhadap guru. Wawancara ini bertujuan untuk menganalisis masalah yang dialami siswa. Hal-hal yang ditanyakan antara lain terkait siswa, biodata guru mata pelajaran matematika, materi pembelajaran, strategi pembelajaran, dan media pembelajaran. Berdasarkan studi pendahuluan yang dilakukan pada salah satu sekolah yaitu SMP Koperasi Pontianak dimana lewat penelitian sebelumnya diberikan instrumen soal kemampuan berpikir tingkat tinggi yang telah dikembangkan kepada siswa dimana hasil yang didapatkan terkait hasil analisis indeks kesukaran soal butir soal dimana semua soal masih tergolong soal sukar (Susiaty \& Oktaviana, 2019). Hal ini menunjukkan bahwa siswa belum terbiasa dihadapkan dengan soal dengan tingkat kemampuan berpikir tingkat tinggi. Padahal sekolah tersebut telah menggunakan kurikulum 2013 namun berdasarkan wawancara yang dilakukan dengan salah satu guru juga menyatakan bahwa pada saat pembelajaran siswa juga tidak difokuskan pada pemberian soal dengan kemampuan berpikir tingkat tinggi namun lebih banyak diberikan soal kepada kemampuan berpikir tingkat rendah. Pada saat pembelajaran, guru juga masih menggunakan metode ceramah dan tanya jawab. Pembelajaran dengan menggunakan metode tersebut belum mendorong siswa belajar secara mandiri. Bahan ajar yang digunakan di sekolah masih berupa buku paket dan
LKS dimana LKS yang digunakan marupakan terbitan dari penerbit. Buku paket dan LKS yang digunakan ini hanya berisi materi, contoh soal, dan soal-soal yang masih monoton dan tidak sesuai kebutuhan siswa artinya dalam buku paket dan LKS tidak memuat aktivitas belajar yang melibatkan siswa secara langsung dalam menemukan dan menerapkan konsep matematika.

Berdasarkan hasil wawancara, guru menyimpulkan bahwa siswa tidak memahami soal kemampuan berpikir tingkat tinggi dikarenakan siswa belum terbiasa dihadapkan pada soal dengan tingkat kemampuan berpikir tingkat tinggi, namun lebih banyak diberikan soal kepada kemampuan berpikir tingkat rendah. Oleh karena itu, dipilih materi perbandingan untuk dijadikan materi penelitian. Adapun model pembelajaran yang digunakan sekolah tersebut adalah model pembelajaran Problem Based Learning dengan pendekatan scientific. Selain itu, media pembelajaran yang pernah digunakan disekolah tersebut adalah infocus dan LKS. Untuk itu, dilakukan pengembangan modul pembelajaran matematika berbasis strategi HOT terhadap kemampuan berpikir tingkat tinggi siswa SMP yang diharapkan dapat memudahkan siswa untuk memahami dan menyelesaikan masalah non rutin sehingga meningkatkan kemampuan berpikir tingkat tinggi siswa. Selanjutnya berdasarkan hasil pra observasi didapati siswa masih kesulitan menyelesaikan soal kemampuan berpikir tingkat tinggi karena tidak terbiasanya dalam mengerjakan soal non rutin dalam hal ini soal yang mengukur kemampuan berpikir tingkat tinggi pada materi perbandingan.

Pada tahap perancangan dalam penelitian ini, disusun instrumen untuk menilai kevalidan, kepraktisan, dan 
keefektifan modul. Penyusunan instrumen tes dibagi menjadi 2 langkah, yaitu : (1) pada langkah pertama, disusun kisi-kisi lembar validasi, kisikisi angket, dan kisi-kisi soal. Kisi-kisi angket dalam aspek materi yang disusun sebanyak 4 aspek yaitu, kelayakan isi (12 butir pertanyaan), kelayakan penyajian ( 9 butir pertanyaan), penilaian bahasa ( 9 butir pertanyaan), penilaian strategi HOT (1 butir pertanyaan). Sedangkan aspek media disusun sebanyak 1 aspek yaitu, aspek kelayakan kegrafikan dengan 3 indikator antara lain ukuran modul (2 butir pertanyaan), desain sampul (5 butir pertanyaan) dan desain isi (7 butir pertanyaan); (2) pada langkah kedua, peneliti menyusun lembar validasi, angket dan soal uji coba sesuai dengan kisi-kisi yang telah dibuat pada langkah pertama. Butir pertanyaan yang diperoleh dari ahli materi 35 butir pertanyaan dan ahli media 24 butir pertanyaan sehingga total pertanyaan sebanyak 59 butir pertanyaan. Tahap berikutnya, kegiatan yang dilakukan adalah mendesain modul. Hasil desain awal modul pembelajaran matematika berbasis strategi HOT terhadap kemampuan berpikir tingkat tinggi siswa SMP dapat dilihat pada Gambar 1.

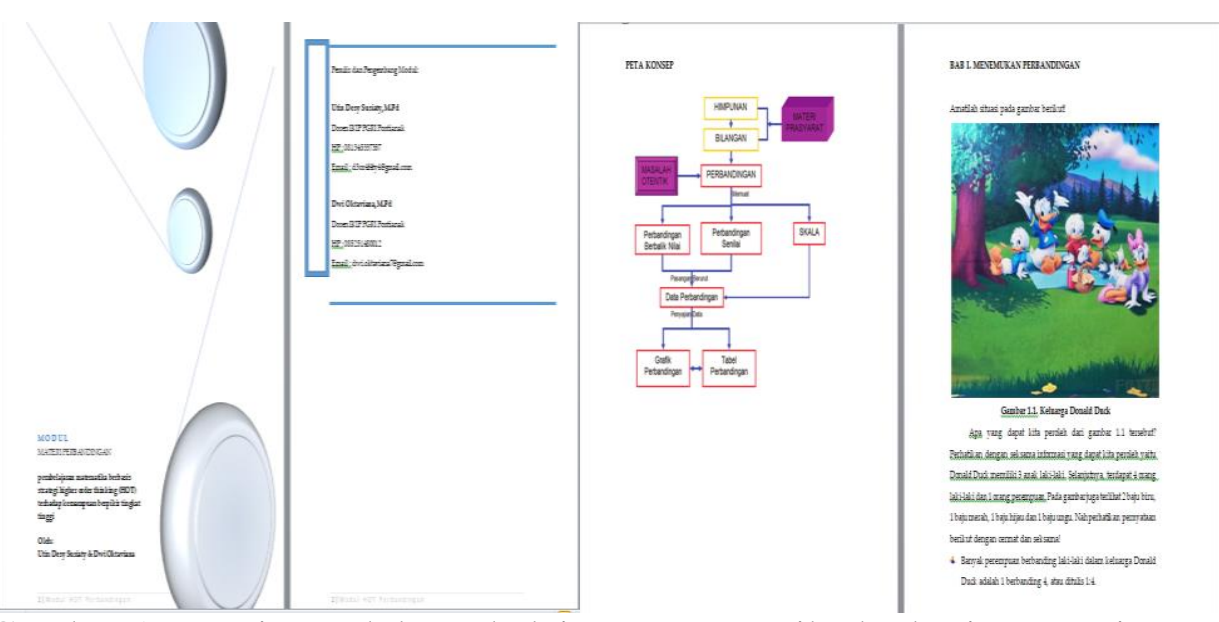

Gambar 1. Desain modul pembelajaran matematika berbasis strategi HOT.

Gambar 1 menampilkan identitas modul, peta konsep, dan contoh salah satu materi dalam modul. Terlihat bahwa modul disusun sedemikian rupa sehingga tidak lagi memberi tahu konsep atau materi melainkan membangun konsep atau materi. Setelah dilakukan pembuatan desain, maka langkah selanjutnya adalah tahap pengembangan modul.

Tahap pengembangan dalam penelitian ini bertujuan untuk memperbaiki modul yang akan dikembangkan dengan melakukan evaluasi dan revisi sebelum menjadi produk yang valid, praktis dan efektif. Validasi digunakan untuk mengetahui kevalidan modul. Validasi dilakukan oleh 3 orang ahli yang masing-masing ahli menjadi ahli media, ahli materi, dan validator soal uji coba serta validator angket. Artinya ketiga validator menilai dan memberikan saran apa saja yang harus diperbaiki dari modul dan menilai valid atau tidaknya modul. Hasil dari uji kevalidan yang dilakukan oleh amsingmasing validator dapat dilihat pada Tabel 1, serta kriteria kevalidan modul disesuaikan dengan Tabel 2. 
DOI: https://doi.org/10.24127/ajpm.v10i1.3154

Tabel 1. Hasil kevalidan.

\begin{tabular}{cccc}
\hline Nomor Ahli & Nilai (\%) & Rata-rata & Kriteria \\
\hline Ahli I & $92,4 \%$ & & \\
Ahli II & $94,2 \%$ & $91,74 \%$ & Sangat Valid \\
Ahli III & $88,63 \%$ & & \\
\hline
\end{tabular}

Tabel 2. Tingkat kevalidan produk.

\begin{tabular}{ccc}
\hline Penilaian & Skala Nilai & $\begin{array}{c}\text { Hasil Rating } \\
\text { Persentase (\%) }\end{array}$ \\
\hline Sangat Valid & 5 & $86 \%-100 \%$ \\
Valid & 4 & $66 \%-85 \%$ \\
Cukup Valid & 3 & $51 \%-65 \%$ \\
Tidak Valid & 2 & $36 \%-50 \%$ \\
Sangat Tidak Valid & 1 & $20 \%-35 \%$ \\
\hline
\end{tabular}

Sumber: (Riduwan, 2016)

Berdasarkan Tabel 1 dan Tabel 2, dapat disimpulkan hasil persentase ratarata dari ketiga ahli adalah $91,74 \%$ dan tergolong kriteria sangat valid. Soal uji coba yang divalidasi oleh semua ahli juga tergolong valid semua dan dapat diujicobakan. Selain itu, dilakukan perbaikan pada modul sehingga menghasilkan modul baru yang telah direvisi.

Sesuai dengan latar belakang dikembangkannya modul ini, maka uji coba lapangan dilakukan di SMP Koperasi Pontianak khusus pada siswa kelas VII. Hari pertama penelitian, guru matematika memberikan pengajaran kepada siswa dengan menerapkan modul pembelajaran matematika berbasis strategi HOT terhadap kemampuan berpikir tingkat tinggi siswa SMP. Siswa terlihat antusias dalam mengikuti pembelajaran, baik dalam menerima materi, memahami masalah, membahas contoh soal, serta mengerjakan soal-soal latihan yang terdapat dalam modul dengan langkahlangkah yang telah disediakan didalam modul tersebut.

Hari kedua penelitian, guru meminta siswa untuk mengerjakan soal posttest dengan menggunakan soal uji coba. Pengerjaan posttest ini digunakan untuk melihat keefektifan dari modul tersebut. Soal diberikan kepada siswa dengan waktu pengerjaan selama $2 \times 45$ menit. Hari ketiga, diberikan angket respon kepada seluruh siswa untuk menilai modul yang telah digunakan. Angket berfungsi untuk menilai kepraktisan dari modul pembelajaran matematika berbasis strategi HOT terhadap kemampuan berpikir tingkat tinggi siswa SMP ini. Guru memberikan waktu 1 jam pelajaran untuk mengisi angket tersebut. Setelah itu, angket tersebut dikumpulkan kembali.

$$
\text { Angket dihitung untuk }
$$
mendapatkan nilai persentase kepraktisan. Nilai kepraktisan dilihat dari hasil lembar respon siswa. Adapun hasil yang diperoleh disajikan pada Tabel 3. Kemudian hasil persentase kepraktisan dikategorikan sesuai dengan kriteria pada Tabel 4.

Tabel 3. Nilai kepraktisan.

\begin{tabular}{cc}
\hline Rata-rata & Kriteria \\
\hline $82,26 \%$ & Sangat Praktis \\
\hline
\end{tabular}


DOI: https://doi.org/10.24127/ajpm.v10i1.3154

Tabel 4. Tingkat kepraktisan produk.

\begin{tabular}{lccl}
\hline \multicolumn{1}{c}{ Penilaian } & $\begin{array}{c}\text { Skala } \\
\text { Nilai }\end{array}$ & $\begin{array}{c}\text { Hasil Rating } \\
\text { Persentase }(\%)\end{array}$ & \multicolumn{1}{c}{ Keterangan } \\
\hline Sangat Praktis & 5 & $86 \%-100 \%$ & Tidak Revisi \\
Praktis & 4 & $66 \%-85 \%$ & Tidak Revisi \\
Cukup Praktis & 3 & $51 \%-65 \%$ & Sedikit Revisi \\
Tidak Praktis & 2 & $36 \%-50 \%$ & Revisi \\
Sangat Tidak Praktis & 1 & $20 \%-35 \%$ & Revisi \\
\hline
\end{tabular}

Sumber: (Riduwan, 2016)

Berdasarkan Tabel 3 dan Tabel 4, dapat disimpulkan hasil perhitungan angket respon siswa dalam penelitian ini dengan persentase rata-rata sebesar $82,26 \%$ dan tergolong kriteria sangat praktis. Artinya, modul pembelajaran matematika berbasis strategi HOT terhadap kemampuan berpikir tingkat tinggi siswa SMP ini praktis digunakan siswa kelas VII. Untuk hasil pengerjaan pretest dan posttest digunakan untuk mengetahui keefektifan modul ini. Hasil yang diperoleh adalah dengan melakukan pengujian hipotesis untuk mengetahui apakah terdapat peningkatan kemampuan berpikir tingkat tinggi siswa kelas VII SMP Koperasi Pontianak setelah diterapkan strategi HOT. Sebelumnya dilakukan perhitungan pengujian normalitas terhadap data kemampuan berpikir tingkat tinggi pretest dan posttest dimana dapat dilihat pada Tabel 5.

Tabel 5. Ringkasan hasil uji normalitas.

\begin{tabular}{|c|c|c|c|}
\hline \multicolumn{4}{|c|}{ One-Sample Kolmogorov-Smirnov Test } \\
\hline & & pretest & posttest \\
\hline \multicolumn{2}{|l|}{$\mathrm{N}$} & 35 & 35 \\
\hline \multirow[t]{2}{*}{ Normal Parameters ${ }^{a}$} & Mean & 35.06 & 60.09 \\
\hline & Std. Deviation & 10.281 & 10.920 \\
\hline \multirow[t]{3}{*}{ Most Extreme Differences } & Absolute & .115 & .097 \\
\hline & Positive & .115 & .068 \\
\hline & Negative & -.089 & -.097 \\
\hline Kolmogorov-Smirnov $Z$ & & .682 & .573 \\
\hline Asymp. Sig. (2-tailed) & & .740 & .898 \\
\hline
\end{tabular}

Berdasarkan Tabel 5 diketahui bahwa nilai signifikansi Asyimp.Sig (2tailed) sebesar 0,740 dan 0,898. Hasil tersebut lebih besar dari 0,05 (taraf signifikansi atau $\alpha$. Oleh karena itu, sesuai dengan dasar pengambilan keputusan dalam uji normalitas Kolmogorov-Smirnov tersebut, dapat disimpulkan bahwa data berdistribusi normal. Dengan demikian, asumsi atau normalitas sebagai prasyarat dalam melakukan uji-t sudah terpenuhi. Selanjutnya dilakukan uji hipotesis dengan menggunakan uji-t. Hasil dari uji hipotesis dapat dilihat pada Tabel 6 . 
DOI: https://doi.org/10.24127/ajpm.v10i1.3154

Tabel 6. Ringkasan hasil uji hipotesis.

\begin{tabular}{|c|c|c|c|c|c|c|c|c|}
\hline \multicolumn{9}{|c|}{ Paired Samples Test } \\
\hline & \multicolumn{5}{|c|}{ Paired Differences } & \multirow{3}{*}{$\mathrm{T}$} & \multirow{3}{*}{ df } & \multirow{3}{*}{$\begin{array}{l}\text { Sig. (2- } \\
\text { tailed) }\end{array}$} \\
\hline & \multirow[t]{2}{*}{ Mean } & \multirow{2}{*}{$\begin{array}{l}\text { Std. } \\
\text { Deviati } \\
\text { on }\end{array}$} & \multirow{2}{*}{$\begin{array}{l}\text { Std. } \\
\text { Error } \\
\text { Mean }\end{array}$} & \multicolumn{2}{|c|}{$\begin{array}{l}\text { 95\% Confidence } \\
\text { Interval of the } \\
\text { Difference }\end{array}$} & & & \\
\hline & & & & Lower & Upper & & & \\
\hline $\begin{array}{ll}\text { Pair } & \text { pretest - } \\
1 & \text { posttest }\end{array}$ & -25.029 & 8.750 & 1.479 & -28.034 & -22.023 & 16.923 & 34 & .000 \\
\hline
\end{tabular}

Berdasarkan Tabel 6 diperoleh nilai Sig. (2-tailed) uji t Paired adalah 0,000 lebih kecil dari 0,05 yang artinya terdapat peningkatan yang signifikan antara nilai pretest dan posttest yang telah diberikan. Peningkatan kemampuan berpikir tingkat tinggi tersebut terjadi karena siswa yang awalnya kesulitan dalam menyelesaikan soal yang memuat indikator menganalisis, mengevaluasi dan mengkreasi setelah diterapkan strategi HOT siswa telah dapat menyelesaikan soal yang memuat indikator tersebut. Lewat penerapan strategi $H O T$ antusias siswa mengalami peningkatan dalam pembelajaran sehingga terjadi peningkatan kemampuan berpikir tingkat tinggi dari siswa itu sendiri. Berdasarkan hasil peningkatan tersebut maka modul pembelajaran matematika berbasis strategi HOT terhadap kemampuan berpikir tingkat tinggi siswa SMP ini efektif digunakan siswa kelas VII. Setelah diuji coba dilapangan, modul ini siap dikemas menjadi produk akhir. Berdasarkan hasil kevalidan, kepraktisan, dan keefektifan yang telah diperoleh dari penelitian ini, maka dapat disimpulkan bahwa modul pembelajaran matematika berbasis Strategi HOT terhadap kemampuan berpikir tingkat tinggi siswa SMP dinyatakan layak untuk digunakan pada siswa kelas VII.
Keterbatasan dalam penelitian yaitu penelitian ini tidak dilanjutkan hingga tahapan yang terakhir yaitu tahap penyebaran. Hal ini dikarenakan keterbatasan waktu dan biaya, dan modul ini hanya membahas materi perbandingan dengan pertimbangan banyak soal non rutin yang dapat dikembangkan dari materi tersebut, serta modul ini hanya digunakan di lingkungan SMP Koperasi Pontianak.

Kesuksesan penelitian ini sejalan dengan penelitian yang dilakukan oleh Anisah \& Lastuti (2018) menyimpulkan bahwa pengembangan bahan ajar berbasis HOTS layak digunakan untuk meningkatkan kemampuan pemecahan masalah matematis mahasiswa. Demikian juga dengan penelitian yang dilakukan oleh Rofiah et al (2018) menyimpulkan bahwa modul pembelajaran IPA berbasis HOTS yang dikembangkan memenuhi kriteria kelayakan pada aspek isi dan penyajian, bahasa, kegrafikan, dan aspek pembelajaran HOTS dalam kategori sangat baik. Sejalan juga dengan hasil penelitian yang dilakukan oleh Wati et al (2019) menyimpulkan bahwa pengembangan modul fisika interaktif berbasis HOTS dalam kategori valid, efektif pada kategori sedang dan mengalami peningkatan dilihat dari peningkatan nilai pretest dan posttest siswa. Berdasarkan hasil penelitian yang relevan tersebut menunjukkan bahwa 
pengembangan modul pembelajaran berbasis strategi HOT memenuhi kriteria kelayakan dalam kemampuan berpikir (kognitif) siswa. Hal ini dikarenakan modul pembelajaran matematika berbasis strategi HOT yang dikembangkan dapat membantu siswa dalam mengembangkan kemampuan berpikir siswa dengan menyodorkan berbagai soal non rutin yang selama ini jarang diperoleh dalam pembelajaran matematika.

Kelebihan modul pembelajaran matematika berbasis Strategi Higher Order Thinking (HOT) termasuk media cetak seperti buku teks. Menurut Dengan ketebalan yang standar dibanding dengan buku teks biasa maka, modul yang dibuat akan mudah untuk dipelajari kapan dan dimanapun serta praktis digunakan. Penyusunan modul berdasarkan kumpulan soal-soal non rutin yang sesuai dengan tingkat perkembangan kemampuan berpikir tingkat tinggi siswa. Modul didesain dengan tampilan yang lengkap dengan perpaduan teks, gambar dan warna sehingga dapat menambah daya tarik siswa untuk membaca, serta dapat memperlancar pemahaman informasi yang disajikan dalam dua format yaitu verbal dan visual. Kekurangan modul terletak pada proses percetakan yang memakan waktu mengakibatkan modul yang dibuat tidak dalam waktu yang singkat. Kekurangan yang selanjutnya yaitu media bahan cetak cepat rusak dan robek jika kualitas cetakan dan kertasnya buruk serta media cetak kurang praktis digunakan pada masa pandemi dikarenakan harus langsung dibagikan kepada siswa.

Implikasi penelitian yaitu secara teoritis modul ini memberikan pengaruh yang besar dalam meningkatkan kemampuan berpikir tingkat tinggi siswa dikarenakan dalam modul tersebut berisi soal-soal non rutin yang selama ini jarang diberikan oleh guru pada pembelajaran matematika di kelas dan berdasarkan hasil penelitian modul memenuhi kriteria kriteria valid dengan kategori sangat valid, kriteria praktis dengan kategori sangat praktis; dan memenuhi kriteria efektif. Secara penerapan menjadi referensi bagi guru untuk dikemudian hari berusaha mengembangkan modul serupa dengan materi pembelajaran matematika yang lain sebagai bahan ajar yang tepat dalam meningkatkan kemampuan berpikir tingkat tinggi siswa sehingga tujuan pembelajaran matematika pun tercapai.

\section{KESIMPULAN DAN SARAN}

Berdasarkan hasil pengembangan, penelitian, dan pembahasan terhadap modul pembelajaran matematika berbasis strategi HOT terhadap kemampuan berpikir tingkat tinggi siswa SMP dapat simpulkan bahwa modul pembelajaran matematika berbasis strategi HOT terhadap kemampuan berpikir tingkat tinggi siswa SMP memenuhi kriteria valid dengan kategori sangat valid, kriteria praktis dengan kategori sangat praktis; dan memenuhi kriteria efektif.

Saran dari penelitian ini agar dapat menjadi pandangan bagi pembaca dan peneliti selanjutnya antara lain: (1) modul yang dikembangkan dalam penelitian ini dapat dilanjutkan lagi oleh peneliti lain ke tahap disseminate atau penyebaran dalam kelas lain, sekolah lain dan dalam skala yang lebih luas; (2) jika peneliti ingin melanjutkan penelitian ini ke tahap disseminate dapat melanjutkan penelitian ini tidak hanya dalam ruang lingkup kota Pontianak saja, tapi juga bisa meneliti ke daerah lain; (3) modul yang dikembangkan masih perlu disempurnakan lagi dengan desain 
modul yang lebih menarik dan dengan melakukan uji coba lebih lanjut dalam tahap disseminate, agar dapat menghasilkan produk yang lebih baik lagi.

\section{DAFTAR PUSTAKA}

Anggoro, B. S. (2015). Pengembangan Modul Matematika Dengan Strategi Problem Solving untuk Mengukur Tingkat Kemampuan Berpikir Kreatif Matematis Siswa. Al-Jabar: Jurnal Pendidikan Matematika, 6(2), 121-129. http://ejournal.radenintan.ac.id/ind ex.php/al-jabar/article/view/25/436 Anisah, \& Lastuti, S. (2018). Pengembangan Bahan Ajar berbasis HOTS untuk Meningkatkan Kemampuan Pemecahan Masalah Matematis Mahasiswa. Kreano: Jurnal Matematika Kreatif-Inovatif, 9(2), 191-197.

https://doi.org/10.15294/kreano.v9i 2.16341

Fitriani, D., Suryana, Y., \& Hamdu, G. (2018). Pengembangan Instrumen Tes Higher-Order Thinking Skill pada Pembelajaran Tematik Berbasis Outdoor Learning di Sekolah Dasar Kelas IV. Indonesian Journal of Primary Education, $2(1), \quad 87$. https://doi.org/10.17509/ijpe.v2i1. 13752

Istiyono, E., Mardapi, D., \& Suparno, S. (2014). Pengembangan Tes Kemampuan Berpikir Tingkat Tinggi Fisika (PysTHOTS) Peserta Didik SMA. Jurnal Penelitian Dan Evaluasi Pendidikan, 18(1), 1-12. https://doi.org/10.21831/pep.v18i1. 2120

Kurniati, D., Harimukti, R., \& Jamil, N. A. (2016). Kemampuan berpikir tingkat tinggi siswa SMP di
Kabupaten Jember dalam menyelesaikan soal berstandar PISA. Jurnal Penelitian Dan Evaluasi Pendidikan, 20(2), 142155.

https://doi.org/10.21831/pep.v20i2. 8058

Lestari, W., \& Handayani, S. (2018). Pengembangan Modul Matematika Berbasis Matematika Realistik Untuk Kelas VII SMP Semester I. Jurnal Analisa, 4(1), 51-60.

Mardiah, S., Widyastuti, R., \& Rinaldi, A. (2018). Pengembangan Modul Pembelajaran Matematika Berbasis Etnomatematika Menggunakan Metode Inkuiri. Desimal: Jurnal Matematika, $\quad 1(2), \quad 119$. https://doi.org/10.24042/djm.v1i2. 2228

Mustapa, K. (2014). Pengaruh Strategi Pembelajaran terhadap Kemampuan Berpikir Tingkat Tinggi. Jurnal Pendidikan Humaniora, 2(4), 348-357. http://journal.um.ac.id/index.php/jp $\mathrm{h}$

Oktaviana, D., \& Susiaty, U. D. (2020). Development of Test Instruments Based on Revision of Bloom's Taxonomy to Measure the Students' Higher Order Thinking Skills. JIPM (Jurnal Ilmiah Pendidikan Matematika), 9(1), 21. https://doi.org/10.25273/jipm.v9i1. 5638

Retnoasih, N. (2018). Implementasi Pembelajaran HOTS ( Higher Order Thinking Skill ) IPA Menggunakan Alat Sederhana. Jurnal Penelitian Pendidikan Matematika Dan Sains, 2(2), 4853.

Riduwan. (2016). Dasar-Dasar Statistika. CV. Alfabeta.

Rizta, A., Zulkardi, Z., \& Hartono, Y. (2013). Pengembangan Soal 
DOI: https://doi.org/10.24127/ajpm.v10i1.3154

$\begin{array}{lcr}\text { Penalaran } & \text { Model } & \text { Timss } \\ \text { Matematika } & \text { SMP. } & \text { Jurnal } \\ \text { Penelitian } & \text { dan } & \text { Evaluasi } \\ \text { Pendidikan, } & 17(2), & 230-240 .\end{array}$
https://doi.org/10.21831/pep.v17i2. 1697

Rofiah, E., Aminah, N. S., \& Sunarno, W. (2018). Pengembangan Modul Pembelajaran IPA Berbasis High Order Thinking Skill (HOTS) Untuk Meningkatkan Kemampuan Berpikir Kritis Siswa Kelas VIII SMP/MTs. INKUIRI: Jurnal Pendidikan IPA, 7(2), 285. https://doi.org/10.20961/inkuiri.v7i 2.22992

Saregar, A., Latifah, S., \& Sari, M. (2016). Efektivitas Model Pembelajaran CUPs: Dampak Terhadap Kemampuan Berpikir Tingkat Tinggi Peserta Didik Madrasah Aliyah Mathla'ul Anwar Gisting Lampung. Jurnal Ilmiah Pendidikan Fisika Al-Biruni, 5(2), 233.

https://doi.org/10.24042/jpifalbirun i.v5i2.123

Sugiyono. (2016). Metode Penelitian Kuantitatif, Kualitatif dan $R \& D$. PT Alfabeta.

Susiaty, U. D., \& Oktaviana, D. (2019). Analisis Kebutuhan Instrumen Tes Berdasarkan Revisi Taksonomi Bloom Untuk Mengukur Higher Order Thinking Skills Siswa. Proceedings of the 1st ICOLED IKIP-PGRI Pontianak, 171-178.
Tjiptiany, E., As'ari, A., \& Muksar, M. (2016). Pengembangan Modul Pembelajaran Matematika Dengan Pendekatan Inkuiri Untuk Membantu Siswa SMA Kelas X Dalam Memahami Materi Peluang. Jurnal Pendidikan - Teori, Penelitian, Dan Pengembangan, 1(10), 1938-1942. https://doi.org/10.17977/jp.v1i10.6 973

Wati, R. W. I., Lesmono, A. D., \& Prastowo, S. H. B. (2019). Pengembangan Modul Fisika Interaktif Berbasis HOTS (High Order Thinking Skill) untuk Meningkatkan Kemampuan Literasi Sains Siswa SMA pada Pokok Bahasan Suhu dan Kalor. Jurnal Pembelajaran Fisika, 8(3), 202-207.

Zalukhu, M. C., \& Ziraluo, M. (2018). Pengaruh Strategi Pembelajaran Higher Order Thinking Terhadap Kemampuan Menulis Teks Anekdot Siswa Kelas X Sma Negeri 1 Telukdalam. Jurnal Education and Development Institut Pendidikan Tapanuli Selatan, 6(1), 60-69. 